\title{
Fruit and vegetables - fresh or processed - which are a better source of vitamin C?*
}

\author{
Warzywa i owoce - świeże czy przetworzone - które są lepszym źródłem witaminy C?
}

\author{
Izabela Gutowska1 ${ }^{\bowtie}$, Patrycja Marszałek², Irena Baranowska-Bosiacka³, Agnieszka Łukomska³, \\ Marta Goschorska ${ }^{3}$, Katarzyna Janda ${ }^{4}$ \\ ${ }^{1}$ Pomorski Uniwersytet Medyczny w Szczecinie, Zakład Chemii Medycznej, al. Powstańców Wlkp. 71, 70-111 Szczecin \\ Pomeranian Medical University in Szczecin, Department of Medical Chemistry \\ 2 Pomorski Uniwersytet Medyczny w Szczecinie, Wydział Lekarsko-Biotechnologiczny i Medycyny Laboratoryjnej, ul. Rybacka 1, 70-204 Szczecin \\ Pomeranian Medical University in Szczecin, Faculty of Medical Biotechnology and Laboratory Medicine \\ ${ }^{3}$ Pomorski Uniwersytet Medyczny w Szczecinie, Zakład Biochemii, al. Powstańców Wlkp. 71, 70-111 Szczecin \\ Pomeranian Medical University in Szczecin, Department of Biochemistry \\ ${ }^{4}$ Pomorski Uniwersytet Medyczny w Szczecinie, Katedra i Zakład Żywienia Człowieka i Metabolomiki, ul. Broniewskiego 24, 71-460 Szczecin \\ Pomeranian Medical University in Szczecin, Department of Human Nutrition and Metabolomic \\ $\triangle$ gutowska@pum.edu.pl
}

\begin{abstract}
Introduction: Vitamin $\mathrm{C}$ is an essential component of our diet. Its presence is necessary for normal body functioning. The main sources are fruits and vegetables.

The aim of the study was to evaluate the content of vitamin C in both raw and processed fruits and vegetables and products available commercially in the autumn/winter period.

Materials and methods: The study material comprised 14 types of fruits and vegetables and commercial products made from them, in which we determined the content of vitamin C.
\end{abstract}

Results: Differences were found in vitamin C content between fresh fruits and vegetables vs. processed fruit and vegetable products.

Conclusions: Fresh fruit and vegetables are not always the best source of vitamin C in the autumn/winter season. In some cases, processed fruits and vegetables are richer in this vitamin. Keywords: vitamin C; vegetables; fruit; raw; processed.

\begin{abstract}
ABSTRAKT
Wstęp: Witamina C jest niezbędnym składnikiem ludzkiej diety, koniecznym do prawidłowego funkcjonowania organizmu. Jej głównym źródłem są warzywa i owoce.

Celem pracy była ocena zawartości witaminy $\mathrm{C}$ w surowych warzywach i owocach oraz przetworach owocowo-warzywnych dostępnych w sieciach handlowych w okresie jesienno-zimowym. Materiały i metody: Badaniom poddano 14 gatunków owoców i warzyw świeżych oraz przetworzonych, w których oznaczono zawartość witaminy C.
\end{abstract}

Wyniki: Wykazano różnice w zawartości witaminy C pomiędzy warzywami i owocami świeżymi oraz produktami gotowymi (przetworami z warzyw i owoców) dostępnymi na rynku. Wnioski: W okresie jesieni i zimy nie zawsze najlepszym źródłem witaminy C są świeże warzywa i owoce. W niektórych przypadkach przetworzone surowce roślinne są bogatsze w tę witaminę. Słowa kluczowe: witamina C; warzywa; owoce; świeże; przetworzone.

\section{INTRODUCTION}

These days we enjoy easy access to all kinds of fruit and vegetables, and in many forms - fresh, frozen, dried, pickled or fermented. At the same time, it is also quite difficult to buy a really "fresh" fruit or vegetable. Some of the widely available products are picked before they are ripe, so that they can be transported, sometimes from remote countries, stored multiple times and only then delivered to the stores [1]. Some nutrients in fruit and vegetables, like fibre, minerals and macroelements, are stable, whereas others - like vitamin $\mathrm{C}$ - are not. That is why vitamin $\mathrm{C}$ is a good indicator of the degree of interference in the production process of particular food products. Vitamin $\mathrm{C}$ is the most unstable vitamin. Its activity is related to its chemical structure, hence even minor modifications render it inactive [2].

The content of vitamin $C$ in fruit and vegetables may differ widely, depending on the plants themselves - the species,

\footnotetext{
* Based on selected findings from the master's thesis by Patrycja Marszałek entitled "Analysis of vitamin C levels in raw and processed fruit and vegetables" accepted by the Faculty Board of Medical Biotechnology and Laboratory Medicine at the Pomeranian Medical University in Szczecin. Thesis supervisor: dr hab. n. zdr. Izabela Gutowska. The original comprises: 32 pages, 20 figures, 1 table and 32 literature items.

The project is financed under the program of the Minister of Science and Higher Education under the name "REGIONALNA INICJATYWA DOSKONAŁOŚCI" in 2019-2020. Project No. 002/RID/2018/19 financing amount PLN 12.000.000).
} 
cultivar, ripeness, and then the losses incurred in storage, transport, processing and preparation [2]. The degradation of vitamin $\mathrm{C}$ is accelerated by high temperature (from as little as $40^{\circ} \mathrm{C}$ ), presence of oxygen or ions of heavy metals, a neutral or alkaline environment, as well as sunlight. It is also destroyed by: drying, UV radiation, preservatives and some medications [2, 3]. Significant loss of ascorbic acid is caused by the oxidase family of enzymes, which are released when the cellular structure is ruptured, e.g. during peeling, bruising or chopping. The activity of those enzymes is significantly reduced in an acidic environment and in low temperatures, e.g. during freezing, halting the degradation of vitamin C [2]. After thermal treatment at home, on average $30-60 \%$ of vitamin $C$ is left in fruit and vegetables, but the storage of cooked vegetables, irrespective of the storage temperature (whether at room temperature or in the fridge), leads to even greater losses, up to approx. $60-80 \%$ of vitamin $C[2,3]$.

The term vitamin C (Acidum ascorbicum, (5R)-5-[(1S)1,2-dihydroxyethyl]-3,4-dihydroxy-2(5H)-furanone) encompasses L-ascorbic acid and L-dehydroascorbic acid (the biologically active form). Ascorbic acid is a ketolactone, a strong reducing agent, which through low oxidation in the body turns into L-dehydroascorbic acid. The formation of L-monodehydroascorbic acid is an intermediate in this reaction. These compounds form a reversible redox system in the body [2]. Humans, unlike many animals, are unable to synthesise vitamin C, lacking the relevant enzyme, L-gulonic acid dehydrogenase, which catalyses the final reaction of vitamin C synthesis from D-glucose $[2,4]$. Therefore, this vitamin is an essential dietary component $[2,5]$.

Having regard to the above, the aim of the study was to evaluate the content of vitamin $\mathrm{C}$ in raw fruit and vegetables as well as processed fruit and vegetable products available commercially in the autumn/winter period.

\section{MATERIALS AND METHODS}

\section{Study material}

The content of vitamin C was analysed in 7 species of fresh vegetables (red bell pepper, green parsley, spinach, carrot, cucumber) and 2 species of fresh fruit (strawberry and pineapple), as well as in preserved forms of the same species: frozen, canned, fermented in brine/vinegar, dried and juiced. All samples were bought at the same time in one of Szczecin's hypermarkets.

\section{Determination of vitamin $\mathrm{C}$ in samples}

The content of vitamin $\mathrm{C}$ was determined in prepared samples through extraction of a $3 \mathrm{~g}$ portion with oxalic acid, and subsequent titration of the obtained filtrate with $\mathrm{I}_{2}$ in a KI solution. Iodine molecules react with the starch indicator forming a blue-coloured complex. Its presence marks the endpoint of titration, once equivalence has been achieved. All analyses were repeated 3 times. Figure 1 illustrates the process of the analysis.

\section{Statistical analysis}

Statistical analysis of results was performed using Statistica v10.0 software (StatSoft, Poland). A Shapiro-Wilk test was used to check if data distribution was normal. Because data distribution differed from a normal distribution, parametric tests were not employed. Statistically significant differences between the studied groups were checked using non-parametric Mann-Whitney U tests, with a significance level $p \leq 0.05$.

\section{RESULTS AND DESCRIPTION}

In the fresh produce included in the study, the content of vitamin C ranged between 5.91-131.22 mg/100 g. The red bell pepper was the richest source of ascorbic acid, and cucumber the lowest.

Figure 2 presents vitamin C content in fresh and processed pepper. The amount of the vitamin ranged from $838.08 \mathrm{mg} / 100 \mathrm{~g}$ in lyophilized (freeze-dried) pepper to $55.09 \mathrm{mg} / 100 \mathrm{~g}$ in pickled pepper.

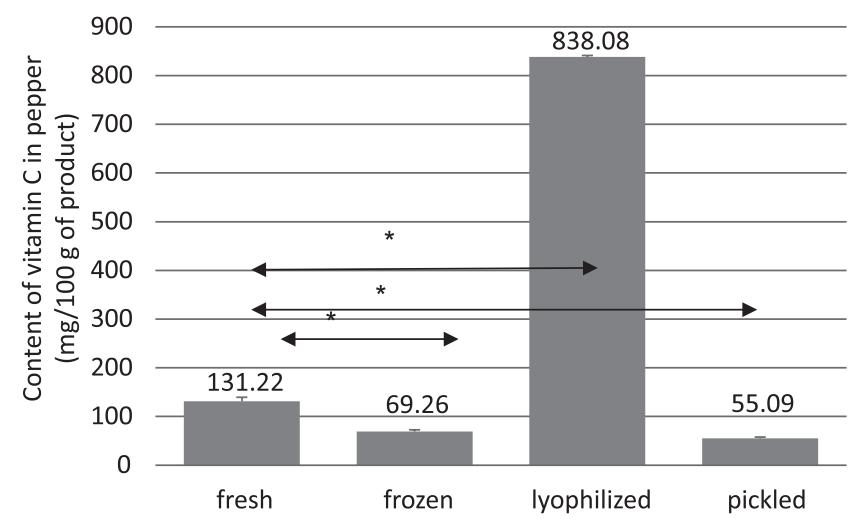

* statistically significant differences at $p<0.05$

FIGURE 2. Content of vitamin C in fresh vs. preserved red bell pepper

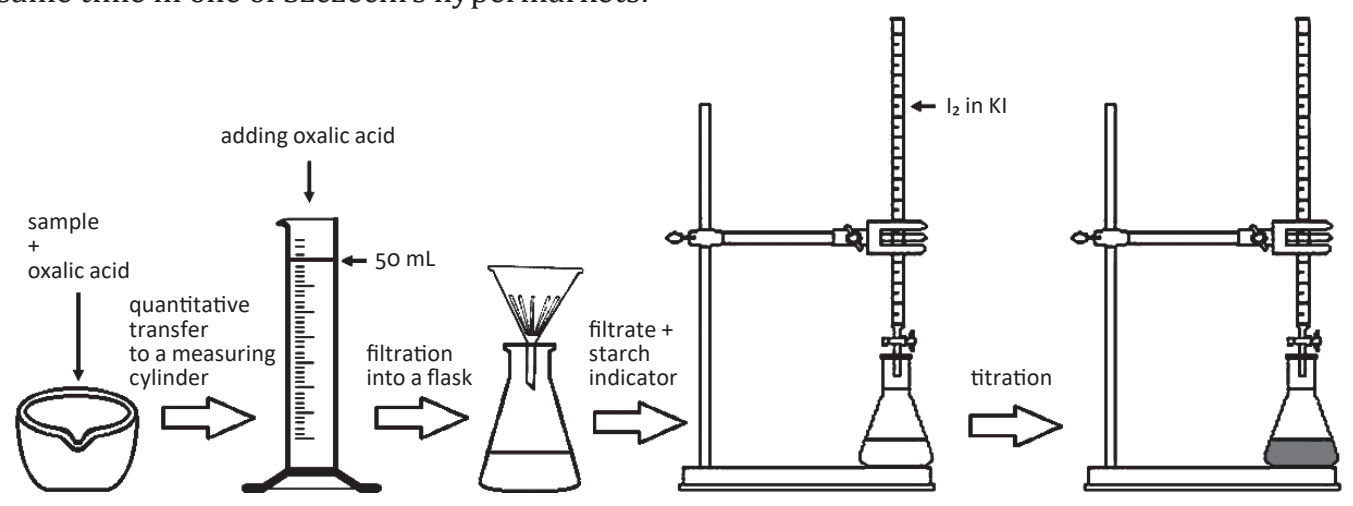

FIGURE 1. Graphic presentation of the study (graphic elements $[6,7,8]$ ) 


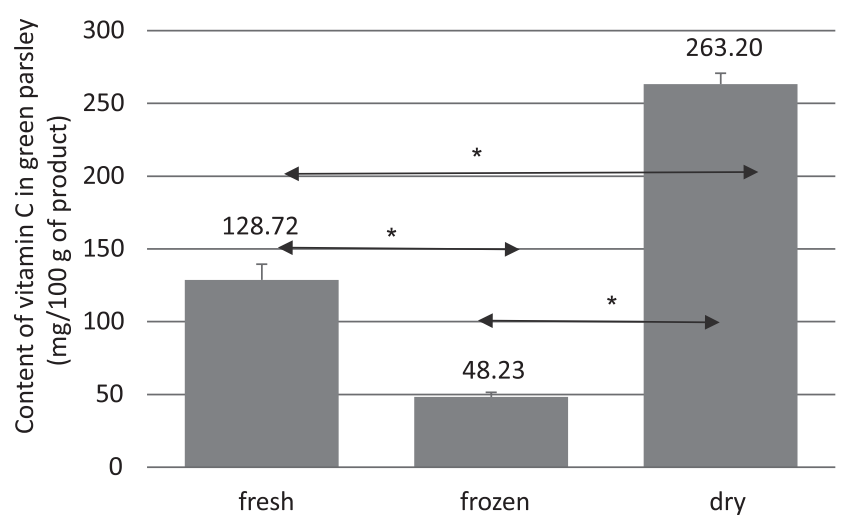

* statistically significant at $p<0.05$

FIGURE 3. Content of vitamin $\mathrm{C}$ in fresh green parsley vs. frozen and dried green parsley

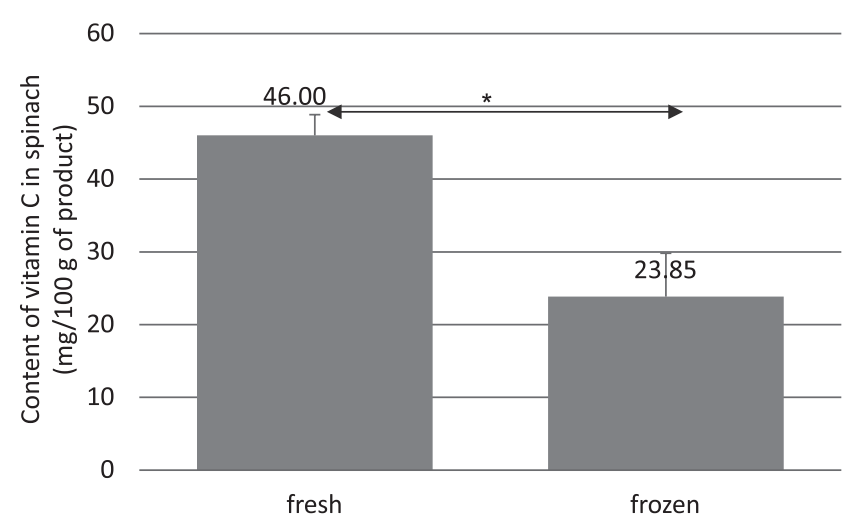

* statistically significant at $p<0.05$

FIGURE 4. Content of vitamin C in fresh vs. frozen spinach

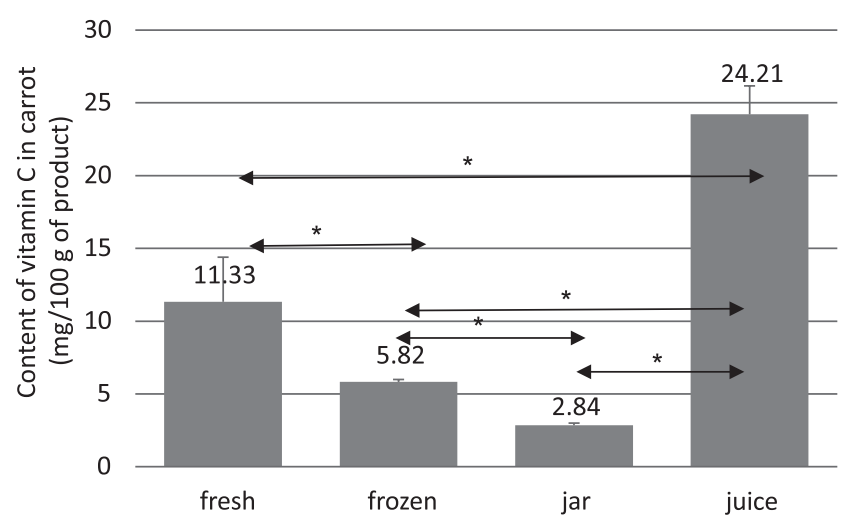

* statistically significant at $p<0.05$

FIGURE 5. Content of vitamin C in fresh carrot vs. processed products

Fresh red bell pepper available in the store at the time contained $131 \mathrm{mg} / 100 \mathrm{~g}$ of vitamin C, and in frozen form $-69.26 \mathrm{mg} / 100 \mathrm{~g}$.

A high content of vitamin $\mathrm{C}$ was also found in fresh green parsley - $128.72 \mathrm{mg} / 100 \mathrm{~g}$ (Fig. 3). It turned out, however, that the best source of vitamin $\mathrm{C}$ was found in dry parsley leaf (263.20 mg/100 g), and the lowest vitamin C content in frozen parsley (48.23 mg/100 g).

Fresh spinach contained $46 \mathrm{mg}$ of vitamin C per $100 \mathrm{~g}$, while frozen - half the amount $(23.85 \mathrm{mg} / 100 \mathrm{~g})$ and the difference was statistically significant (Fig. 4).

Fresh carrot contained $11.33 \mathrm{mg}$ of vitamin C per $100 \mathrm{~g}$, while carrot juice - twice the amount (24.21 mg/100 g); the difference

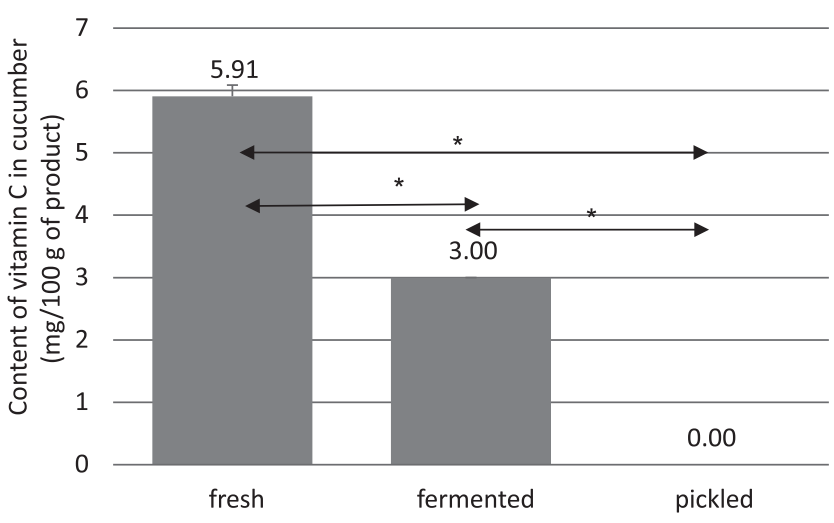

* statistically significant at $p<0.05$

FIGURE 6. Content of vitamin C in fresh cucumber vs. processed products

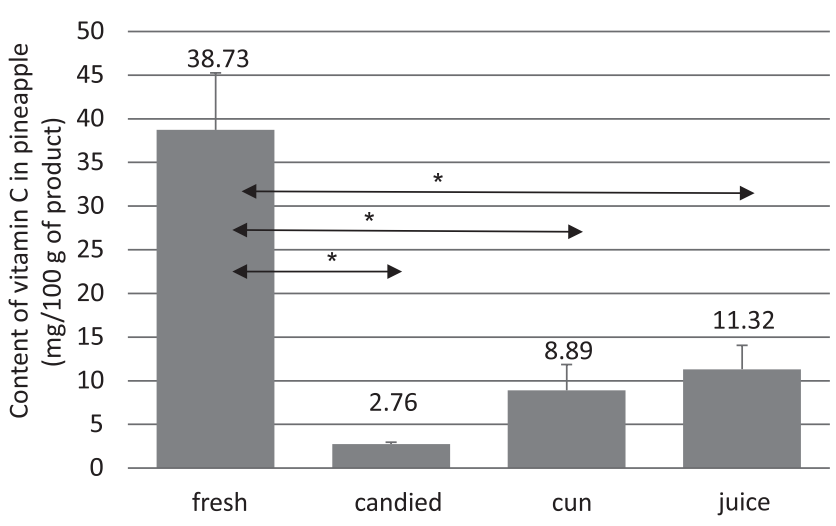

* statistically significant at $p<0.05$

FIGURE 7. Content of vitamin C in fresh pineapple vs. processed products

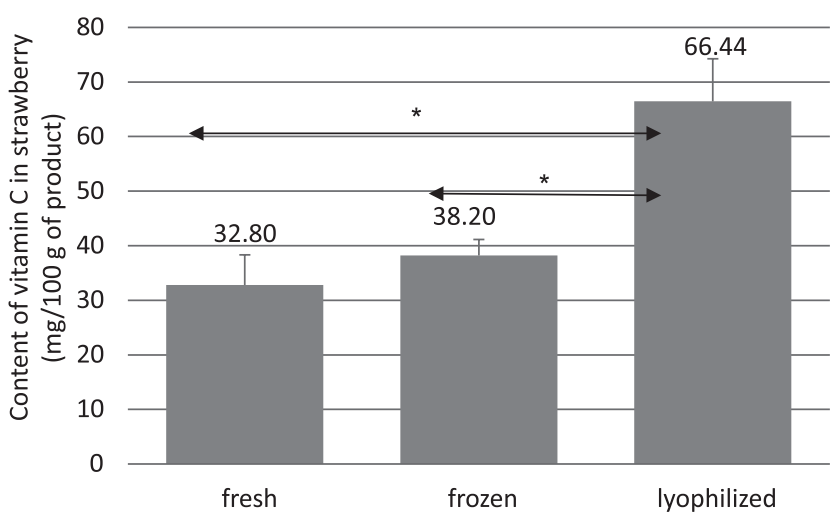

* statistically significant at $p<0.05$

FIGURE 8. Content of vitamin $\mathrm{C}$ in fresh strawberry vs. processed products

was statistically significant. The lowest content of vitamin C was observed in carrot in a jar and frozen carrot, respectively $2.95 \mathrm{mg} / 100 \mathrm{~g}$ and $5.84 \mathrm{mg} / 100 \mathrm{~g}$ (Fig. 5).

Cucumber is not regarded as a vitamin-rich vegetable, which was confirmed by our findings - fresh cucumber contained only $5.99 \mathrm{mg}$ of vitamin C per $100 \mathrm{~g}$, fermented - only $3.00 \mathrm{mg} / 100 \mathrm{~g}$, while pickled cucumber had none whatsoever (Fig. 6).

With respect to pineapple, the highest vitamin $\mathrm{C}$ content was found in fresh fruit ( $38.73 \mathrm{mg} / 100 \mathrm{~g})$. Candied pineapple had the lowest content of vitamin C $(2.96 \mathrm{mg} / 100 \mathrm{~g})$ - Fig. 7.

Lyophilized strawberry contained the highest content of vitamin C (66.44 mg/100 g). This was statistically higher than 
the values determined in fresh fruit $(32.80 \mathrm{mg} / 100 \mathrm{~g})$ and frozen strawberry $(38.21 \mathrm{mg} / 100 \mathrm{~g})$ - Fig. 8.

\section{DISCUSSION}

Vitamin C is water-soluble, which makes it easy for the body to absorb. On the other hand, the same property causes significant losses through every type of treatment, including even washing, steeping or blanching [3].

The analysis of vitamin $\mathrm{C}$ content in the fruits and vegetables included in the study revealed the different amounts in the different species. In fresh produce, the content of vitamin $C$ ranged from 5.91-131.22 mg/100 g. The red bell pepper was the richest source of ascorbic acid, and cucumber the lowest. The results obtained for fresh fruits and vegetables for the most part corresponded to those of other authors. The differences, if any, amounted to a few percentage points, which is normal considering the perishability of vitamin $\mathrm{C}$ and the random choice of specimens (no information on the cultivar or time on the shelf). Yet, in some cases the differences were more significant (strawberries), which may have been due to the time of year the study took place (autumn/winter) and, consequently, the unavailability of fresh local produce.

The fresh strawberries used in the study originated from Spain, where the cultivation of strawberry tends to be more intensive than in Poland, entailing e.g. larger amounts of fertilisers and chemical plant protection products, to preserve the fruit as it travels over long distances. Moreover, winter strawberries are cultivated in special plastic tunnels, where they have limited access to sunlight [9]. All these factors may undermine the nutritional value of the fruit, leading also to a reduced content of vitamin C compared to domestic fruit, which was used in the study in frozen form. This is the likely reason why the frozen strawberries had a higher vitamin $\mathrm{C}$ content than their fresh counterparts, even though freezing causes a decrease in vitamin C levels [10].

The majority of findings from this study (excluding the strawberries) coincide with those of Tosun and Yucecan [10] and Murcia et al. [11], who also observed the loss of vitamin C in frozen vegetables (38.2\% for green beans, $36.2 \%$ for spinach, $29 \%$ for green peas [10] and $51 \%$ for broccoli [11]) compared to fresh produce. Probably, the loss of vitamin $\mathrm{C}$ in frozen products is caused mainly by the treatment preceding freezing, i.e. blanching, which involves a brief thermal treatment of the material with water or steam usually at a temperature of $80-95^{\circ} \mathrm{C}$ (mainly on the surface), followed by immediate cooling down to approx. $15-20^{\circ} \mathrm{C}[12]$. Its purpose is to preserve the colour, to inactivate the enzymes present in the fruit and vegetables and responsible for ripening and loss of sensory qualities, as well as preliminary cleansing of the product [12]. The loss of vitamin $\mathrm{C}$ in frozen products may also be to a lesser extent caused by the formation of ice crystals in fruit and vegetables, which rupture cells walls and, consequently, cellular structures. As a result, upon defrosting, they are more exposed to oxygen, which induces degradation of ascorbic acid [3]. On the other hand, the upside of frozen products is that the material is collected at the best harvesting time for the species, when it has the highest content of vitamins and minerals, and freezing takes place only several hours after harvesting [12].

The appertisation process (preservation of food in an airtight container) is associated with a loss of vitamin C. According to Murcia et al. [11], the (canning) process decreased the ascorbic acid content in broccoli by $84 \%$, and Weits et al. [13] demonstrated a vitamin C loss of $73 \%$ in green peas, $62 \%$ in spinach and $63 \%$ in green beans (all products in cans). Such significant losses of vitamin $\mathrm{C}$ are probably related to the exposure of the vitamin to extended and sudden changes of temperature - different depending on the species or the environmental parameters used in appertisation (such as the temperature, $\mathrm{pH}$, addition of salt) [12].

Preservation of vegetables with the use of acetic acid (vinegar-pickling) also contributed to the loss of vitamin C. It may be caused by several factors, of which the key is high-temperature pasteurisation $\left(85-100^{\circ} \mathrm{C}\right)$ at the end of the technological process [2,3]. According to Yalim and Ozdemir [14] the loss of vitamin $\mathrm{C}$ in pickled pepper compared to the fresh vegetable was $51.8 \%$ after 3 weeks and $59.1 \%$ after 8 weeks of storage. These findings coincide with those obtained by Pobereżny and Wszelaczyńska [15], where the losses amounted to 50\%.

Fermentation is a process conducive to "stabilising" vitamin C. Wojdyła and Wichrowska [16] reported an increase in vitamin C content by $14 \%$ in fermented cabbage (sauerkraut) compared to fresh cabbage. The material used to make sauerkraut - white head cabbage is a rich source of vitamin C by itself, and the characteristics of its fermentation process (including the low $\mathrm{pH}$ and anaerobic conditions) help prevent vitamin $\mathrm{C}$ loss. Grzelakowska et al. [17] found that fermented cucumbers contained less vitamin $\mathrm{C}$ compared to their fresh counterparts, which was probably due to the fermentation method used. Vegetables put into cold water with added salt do not lose vitamin $\mathrm{C}$, which may undergo degradation if hot water were to be used to make fermented cucumbers. Fermented foods have a pH value near 3.5, which is good for vitamin C. Moreover, in an acidic environment ascorbinase - the vitamin C-destroying enzyme found in fresh cucumber, is deactivated [17].

Drying is one of the most common methods for preserving food. The loss of vitamin $\mathrm{C}$ will depend on the drying method used. Typically, plant material is dried in a convection oven, using hot air. In this case, the degradation of vitamin $C$ is due to the influence of a high temperature over an extended period and long-term exposure to oxygen. The best drying method is lyophilisation (freeze-drying) which involves removing the water from pre-frozen material under low pressure. In this method, the material is not exposed to high temperatures, which prevents the loss of vitamin $\mathrm{C}$.

The production of pasteurised potable juice is a lengthy, multi-step process, involving several factors leading to vitamin C degradation. Findings by Kluszczyńska and Sowińska [18] report a $58.5 \%$ loss of vitamin C in blueberry juice compared to fresh blueberry. In Gutkowska et al. study, the high content of vitamin $\mathrm{C}$ in juices compared to the fresh material may be attributed to adding it "artificially" at the end of the 
technological process. Manufacturers justify it saying that they want to increase the nutritional value of the product and preserve the naturally-occurring vitamin which, through storage and various treatments aimed at extending product life, undergoes degradation. One such treatment involves the use of hydrogen peroxide to sterilise and seal Tetra Pak-type packaging. While this extends the shelf life of the juice, traces of hydrogen peroxide induce the oxidation of ascorbic acid [19].

Pursuant to the Regulation of the European Parliament and Council of 20 December 2006, vitamin C may be added to food. Yet, the amount added may not exceed $100 \%$ of the recommended dietary allowance. Vitamin $\mathrm{C}$, along with folic acid, is an exception to the adopted standards (other substances may not exceed 50\% RDA), which is due to its sensitivity to various external factors and, consequently, high losses during processing. For this reason, the labelling should provide information on the overall content of vitamin $\mathrm{C}$ - the sum of naturally-occurring and added vitamin [20].

\section{CONCLUSIONS}

Based on our findings, it can be concluded that eating frozen fruit and vegetables provides relatively high amounts of vita$\min \mathrm{C}$ (in winter, more than the amounts found in the available produce from abroad), while the majority of dried fruit and vegetables, as well as juices, provide the body with more vitamin $\mathrm{C}$ in the same portion than their fresh counterparts.

\section{REFERENCES}

1. Rickman J, Barrett D, Bruhn C. Nutrional comparison of fresh, frozen and canned fruits and vegetables. Part 1. Vitamins C and B and phenolic compounds. J Sci Food Agric 2007;87:930-44.

2. Miktus M. Witaminy. Część II: Ogólna charakterystyka witaminy C. Żywienie i zdrowie 2000;3(1):1-12.
3. Sękowski S. O witaminie C obiektywnie. Młody Technik 2004;9:50-2.

4. Linster C, Van Schaftigen E. Vitamin C, biosynthesis, recycling and degradation in mammals. FEBS J 2007;274(1):1-22.

5. Janda K, Kasprzak M, Wolska J. Witamina C - budowa, właściwości, funkcje i występowanie. Pomeranian J Life Sci 2015;61(4):419-25. doi: 10.21164/ pomjlifesci.427.

6. Procedure for taking measurements by titration. http://www.web-formulas.com/Formulas_of_Chemistry/Process_of_Titration.aspx (12.04.2016).

7. Okuniewski A. Opis szkła laboratoryjnego. http://www.chemmix.edu.pl/ artnet/print.php?s1=02\&s2=001\&s3=001 (12.04.2015).

8. ChemFan electronic mailing list service. http://chemfan.pg.gda.pl/Sprzet_I_ Odczynniki/Sprzet.html (12.04.2015).

9. Sezon na truskawki. Skąd pochodzą truskawki?. http://www.ekologia. pl/srodowisko/ochrona-srodowiska/sezon-na-truskawki-skad-pochodza-truskawki,19461,1.html (18.04.2015).

10. Tosun BN, Yucecan S. Influence of commercial freezing and storage on vitamin C content of some vegetables. Int J Food Sci Tech 2008;43:316-21.

11. Murcia MA, Lopez-Ayerra B, Martinez-Tome M, Vera AM, Garcia-Carmona F. Evolution of ascorbic acid and peroxidase during industrial processing of broccoli. J Sci Food Agric 2000;80:1882-6.

12. Boruch M, Król B. Procesy technologii żywności. Skrypt dla szkół wyższych. Łódź: Politechnika Łódzka; 1993.

13. Weits J, van der Meer MA, Lassche JB, Meyer JC, Steinbuch E, Gersons $\mathrm{L}$. Nutritive value and organoleptic properties of three vegetables fresh and preserved in six different ways. Int J Vitamin Nut Res 1970;40:648-58.

14. Yalim S, Ozdemir Y. Effects of preparation procedures on ascorbic acid retention in pickled hot peppers. Int J Food Sci Nutr 2003;54(4):291-6.

15. Pobereżny J, Wszelaczyńska E. Wpływ metod konserwacji na wybrane cechy jakościowe owoców i warzyw znajdujących się w handlu detalicznym. Inż Ap Chem 2013;52(2):92-4.

16. Wojdyła T, Wichrowska D. Wpływ stosowanych dodatków oraz sposobów przechowywania na jakość kapusty kiszonej. Inż Ap Chem 2014;53(6):424-6.

17. Grzelakowska A, Cieślewicz J, Łudzińska M. The dynamics of vitamin C content in fresh and processed cucumber (Cucumis sativus L.). Chem Didact Ecol Metrol 2013;18(1-2):97-102.

18. Kluszczyńska D, Sowińska W. Wpływ procesów technologicznych na zawartość substancji bioaktywnych w owocach borówki czernicy. Żywn Nauka Technol Jakość 2014;4(95):30-42.

19. Lebiedzińska A, Czaja J, Petrykowska K, Szefer P. Soki i nektary owocowe źródłem witaminy C. Bromat Chem Toksykol 2012;45(3):390-6.

20. Regulation of the European Parliament and of the Council of 20 December 2006 on the addition of vitamins and minerals and of certain other substances to foods (OJ L 404/26). http://eur-lex.europa.eu (21.03.2015). 